\title{
THE EFFECTIVENESS OF THE USE OF METACOGNITION-BASED INDUSTRIAL ELECTRONIC LEARNING TOOLS IN GROWING HIGHER ORDER THINKING SKILLS (HOTS)
}

\author{
Purnamawati \\ Universitas Negeri Makassar \\ purnamawati@unm.ac.id \\ Saliruddin \\ Universitas Negeri Makassar \\ saliruddin48@yahoo.co.id
}

\begin{abstract}
The aims of this research were to: (1) find out the response of students to metacognition-based industrial electronic learning in growing the ability of Higher Order Thinking Skills (HOTS) in vocational secondary schools, (2) describe the learning outcomes of the students in the field of industrial electronics based on metacognition with direct learning method, and (3) generate the effectiveness of metacognition-based industrial electronics learning in growing HOTS capabilities in vocational secondary schools. The research was Quasi-experimental type, while the research design used Pretest-Posttest Control Design with the research subject was the students of Public Vocational Secondary Schools in Makassar City in the field of Industrial Electronics Expertise. Data collection techniques were conducted by questionnaire and learning outcomes test. The result showed that: (1) the students' response of experimental class was higher that control class, (2) the learning outcomes of experimental class was higher than control class, and (3) the use of metacognition-based tools for industrial electronics learning was effective. This learning method could grow the HOTS capabilities of the students in solving the problems of industrial electronics circuit.
\end{abstract}

Keywords: the effectiveness, learning tools, metacognition, industrial electronics, higher order thinking skills 


\section{INTRODUCTION}

The effectiveness of learning model application in education is an important thing to conduct. An effective learning model delivers the students to have competency in facing recent condition, i.e. ability to compete in Business World and Industrial World (Dunia Usaha dan Dunia Industri/DUDI) in ASEAN Economic Community (AEC) era. One of effective learning models today is problem-solving model which delivers the students to solve problems in learning.

Its basic characteristic emphasizes on problem solving ability and higher order thinking, the learning is constructed from the knowledge that previously owned to solve the problems (Sudira, 2016, p. 28). Furthermore, (Trisdiono, 2013) explained that working world demands changes in competence. The ability for critical thinking, solving problems, and collaborating become important competencies in entering the $21^{\text {st }}$ century life. Therefore, the school is required to be able to prepare the students entering the $21^{\text {st }}$ century.

Darmin Nasution tated that the more advanced civilizations, the more competence is required to win the competition. Of course, the government does not remain silent receiving the existing Human Resources (HR) (Kompas, 2016) .Darmin Nasution's statement provided a strong understanding that the competence of graduates is very important to be developed in meeting the global demands.

Sudira (2016, p. 73) explained that the goals of human resource development policy through vocational education are: (1) to create job opportunities for all who need with following criteria: balanced, equitable, free to choose, and provide a decent income; (2) vocational education develops every potential students as a whole; (3) the suitability between humans and jobs with the loss of income and production as small as possible. On the basis of these, the formal education, especially vocational secondary schools, should cooperate with the institutions or DUDI in overcoming the problems and realizing the graduates' competence. On the other hand, the format of vocational education needs to be revitalized in producing graduates who always adapt to changes and demands of globalization or the AEC.
This condition provides the idea that vocational education learning is a learning to produce graduates who are able to work in a particular field Dharma et al. (2013, p. 30). Learning that comes with a good and proper learning tools by itself can help students gain a supportive competence in their field of work.

Learning tools should be able to equip a number of competencies that are expected. This means that the competence of graduates who are able to face work related to the field of expertise. The graduates' competence is not only armed with diploma but is equipped with certification copy which is a regular competency roadmap that can be used as a work attachment to enter the competition in the era of AEC. In addition, the application of diverse learning models in the learning process provides experience for teachers in choosing the right and correct models. Similarly, the use of metacognition-based learning tools in vocational education, especially vocational secondary schools.

Metacognition-based learning tools direct the students to develop Higher Order Thinking Skills (HOTS) skills and learning independence, so that their HOTS ability can develop continuously in every learning activity that eventually becomes habits. Kerka (1992) stated that higher order thinking skills are important skills expressed in thinking, such as the ability to think creatively, make decisions, solve problems, visualize, consider, analyze, interpret, and know how to learn. The characteristics of creative thinkers are diligence, flexibility, metacognition, knowledge transfer, problem orientation, open-mindedness, use of quality standards, and independence. Thus, metacognition is an important indicator in growing HOTS.

The learning tools of metacognitionbased in the field of industrial electronics expertise has a syntax that describes learning systematically. Which means, the learning syntax contains metacognition commands that produce expected competence changes, i.e. the growth of HOTS capabilities that help students in solving project task problems and practices in which the indicators have been expressed by Kerka (1992). Then the learning syntax is modified and adapted to the characteristics of the students. Therefore, teachers 
play an important role in implementing metacognitive syntax for effective learning.

Changes in job characteristics of the the $21^{\text {st }}$ century require an increasingly complex problem-solving ability with HOTS. This learning activity can be observed by giving problems, so that the students are able to think creatively and critically in finding a systematic solution in solving the problem. Finally, the students' ability of HOTS can be grown by giving problems in the field of industrial electronics expertise.

Hopkins (2007) found an effective learning framework, including strategies and skills of teaching, learning relationships, learning models, learning content, and learning reflection. These five components are interrelated and overlap in a framework that must work synergistically and are capable of supporting effective learning to meet the objecttives and learning outcomes required (Faraday, Overton, \& Cooper, 2011, p. 2). Figure 1 is an effective learning development framework developed by Hopkins and Faraday.

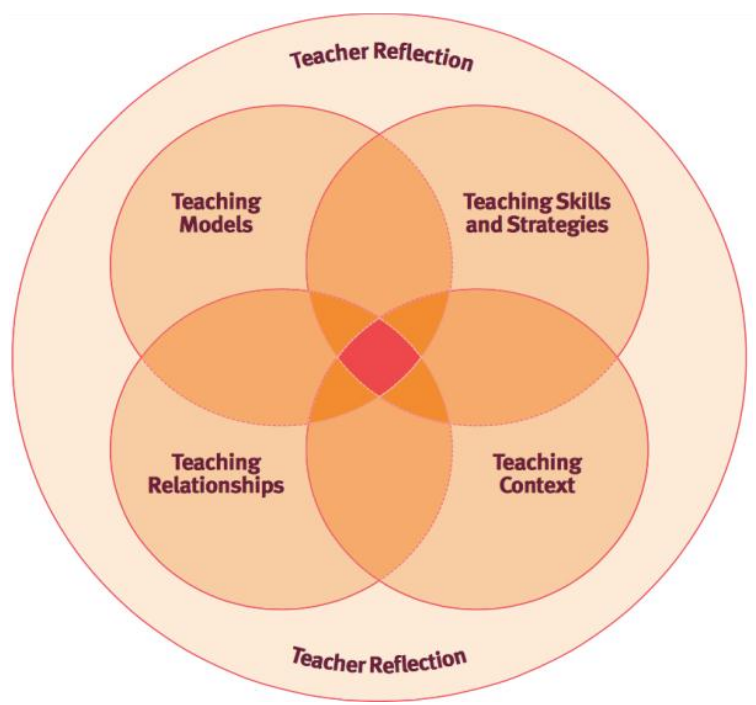

(Hopkins, 2007; Faraday et al., 2011, p. 2)

Figure 1. Framework for the Development of Effective Learning

Learning is said to be effective, if the objective component is achieved as expected in the learning. This means that in this learning, the students can solve problems well, for example, the students are given case studies of 3 problems according to the learning objecttives that can be resolved properly.
Furthermore, Jossberger, BrandGruwel, van de Wiel, \& Boshuizen (2015, p. 287) suggests that teachers play an important role in translating the innovative concepts of educational practice, teachers' perceptions of teaching provide useful information on how best to tailor learning objectives and implementtation of workplace simulations.

Teachers design learning materials and provide pedagogical guidance in work-place simulations. Teachers' readiness in lear-ning needs to be given pedagogical guidance and simulated learning in the industry, so that teachers are ready to help students develop HOTS through metacognitive skills with selfregulation and self-direction to the problems of practice learning. This statement provides an understanding that teachers direct the students in order to foster HOTS capabilities through a metacognitive approach to the developed learning tools.

The students are guided in order to solve practical problems with their own perceptions and abilities, but still patterned on learning objectives. The concept of metacognition is one's way of thinking about the one's own thinking process. This concept was first expressed by Flavell (1979, p. 906) and redeveloped by Livingston (1997), Kung, Danielsson, \& Linder (2005, p. 1), Lee \& Baylor (2006, p. 345), Munby, Hutchinson, \& Chin (2009, p. 1769) and some other experts. Furthermore (Amalathas, 2010, p. 9) emphasized that metacognition is the process of reflecting on one's own learning - is central to learning to learn.

Lai (2011, p. 2) described metacognition as a good and proper teaching, with empirical evidence supporting the idea that students can be taught to reflect on their own thoughts. Furthermore, Lai revealed that metacognition has two components, namely metacognitive knowledge and metacognitive regulation. Metacognitive knowledge includes knowledge of oneself as a learner and factors affecting performance, knowledge of strategy, and knowledge of when and why to use such strategy.

Metacognitive regulation is the monitoring of a person's cognition and includes planning activities, awareness of understanding and performance tasks, and evaluation or effectiveness or monitoring processes and strategies. Lai (2011, p. 4) wrote that Partner- 
ship for $21^{\text {st }}$ Century Skills has identified independent learning as one of the life and career skills necessary to prepare graduates and workers.

Thus, the metacognition-based industrial electronics expertise learning tools involve metacognition commands on the skill package. The field of industrial electronics expertise is one of the skill packages in the Spectrum of Vocational Secondary Education 2013 (Direktur Jenderal Pendidikan Menengah Kementerian Pendidikan dan Kebudayaan, 2013). The learning activities of theory and practice are carried out in the laboratory using an ap-proach or based on metacognition.

The syntax of learning is illustrated in phases I to $\mathrm{V}$ which integrate metacognitive questions in each learning step. The results of this application ultimately foster the ability of critical, creative, and innovative thinking which are the indicators of the realization of HOTS. Critical thinking is the application of the right skills and strategies to get the desired results (Faraday et al., 2011, p. 9). It involves the monitoring of thinking process, to check whether the learning progress fits the desired goal, and ensures its accuracy. For the learning activities of critical thinking, students can be taught metacognitive strategies that help them to control their thinking processes. The contribution of metacognitive strategies fosters critical thinking skills that have implications in learning ( $\mathrm{Ku} \& \mathrm{Ho}, 2010$, p. 251). Lucas, Spencer, \& Claxton (2012, p. 13) explained that most entrepreneurs want employees who are able to think critically in their work, even in vocational education worldwide recognize the importance of critical thinking skills.

Furthermore, Sudira (2016, p. 148) explained that it is time for the TVET (Technical and vocational Education and Training) system to make changes to future educational needs where the learning experiences are selfcultivated in a conscious and planned manner with a strengthening motivation on the adaptability of Old World of Classrooms in the News World of work. This means News World of work requires andro-gogy approach as a process of self-transformation in achieving life skills of the XXI Century, which are: (1) Critical Thinking and Problem Solving; (2) Collaboration Across Networks and Leading by Influence; (3) Agility and adptability;
(4) Initiative and Entrepreneuralism; (5) Effective Oral and Written Communication; (6) Accessing and Analyzing Information; and (7) Curiosity and Imagination.

According to the BSNP 2010 Report that the $21^{\text {st }}$ century learning framework, comprises: (a) Critical-Thinking and ProblemSolving Skills, able to think critically, laterally, and systemically, especially in the context of problem solving; (b) Communi-cation and Collaboration Skills, able to communicate and collaborate effectively with various parties; (c) Creativity and Innovation Skills, able to develop their creativity to produce innovative breakthroughs; (f) Infor-mation and Communications Technology Literacy, able to utilize information and communication technology to improve perfor-mance and daily activities; (g) Contextual Learning Skills, able to undergo contextual independent learning activities as part of personal development, and (h) The ability of information and media literacy, able to understand and use various communication media to convey various ideas and carry out collaboration activities as well as interaction with various parties (Wijaya, Sudjimat, \& Nyoto, 2016).

This explanation provides an understanding on the importance of integrating thinking ability through metacognition strategies in learning tools. If the learning tools are well packaged in accordance with the learning objectives, they will foster HOTS capabilities and produce effective learning.

Learning is effective when it reaches all planned learning objectives. Supardi (2013, p. 164) explained that effectiveness means striving to achieve the objectives that have been defined in accordance with the needs, in accordance with the plan, either in the use of data, means, or time or attempt through certain activities, both physically and nonphysically to obtain maximum results, quantitatively and qualitatively. It is further explained that the effectiveness aspects of a program can be seen based on the clarity of the program, teacher variations in presenting teaching materials, organization of learning environment, and achievement of learning outcomes. According to Susanto (2013, p. 54), learning is said to be effective when there is a positive behavior change and an achievement of learning objectives that have been determined. Furthermore, the learning process is 
said to be successful and qualified when the input is equally distributed, resulting in a large and high quality output and in accordance with the needs of community growth and development.

Based on the above description, it can be concluded that learning is said to be effective if the learning outcomes and learning activities of students in accordance with the objectives that have been established by using metacognition-based learning are better than students who learn by conventional methods at a certain level of mastery. Students learning mastery should be tailored to the Minimum Passing Criteria (Kriteria Ketuntasan Minimal/KKM) that has been established at school. The success of the class is seen from the number of students who are able to complete, which is a minimum of $75 \%$ of the number of students in that class, which meets the KKM learning in the field of industry electronics expertise, that is 2.67 (B-). Based on the illustration, the research of the effectiveness of the use of learning tools in the field of industrial electronic expertise in Vocational Secondary School is urgent to be implemented.

A benchmark for growing HOTS skills and achievement of learning outcomes (academic ability and vocational skills) through systematic practice problem solving according to the learning stage of practice by integrating metacognition questions in each syntax. Academic ability related to the field of adaptive (knowledge) and vocational skills related to the field of expertise (skills) owned. Thus, the effectiveness of the use of learning tools in the field of industrial electronics expertise can be achieved by taking into account indicators of achievement goals and activities of students.

In this regard, the current develop-ment of industrial electronics technology applies various application programs in analy-zing the electronic circuit. These conditions require skills to use the application, analyze and interpret the results in the form of reports. Step-bystep circuit analysis through computer applications requires HOTS thinking skills.

\section{RESEARCH METHOD}

The research was Quasi-experimental research in which the classes were grouped into control class and experimental class pretest-posttest design control model with the experimental class was given treatment with metacognition-based learning approach and control class using direct learning.

The research was conducted in Public Vocational Secondary School of Makassar, with the number of students was 30 persons. The research instruments were questionnaires and learning outcomes test in the field of industrial electronic expertise. Those instruments were validated by 2 experts of electronic skills, then the validity and reliability were tested construc-tively. The research data that had met the criteria valid and reliable were then analyzed by using descriptive and inferential analysis.

\section{THE RESULT OF THE RESEARCH}

\section{Students' Response in the Application of Metacognition-Based Learning Tools}

The average response of students on the learning field of metacognition-based industrial electronics expertise was 83.93. The median was 83 , the mode for the experimental class was 80 , while the variance was 29.34 . The lowest value for the experimental class was 78 and the highest value was 97 with the range of 19 .

Tabel 1. Frequency Distribution of Response of Students of Experimental and Control Class to Metacognition-based Learning

\begin{tabular}{llcccc}
\hline \multirow{2}{*}{ Value } & \multirow{2}{*}{ Category } & \multicolumn{2}{c}{ Experiment } & \multicolumn{2}{c}{ Control } \\
\cline { 3 - 6 } & & Freq. & $\%$ & Freq. & $\%$ \\
\hline $81-100$ & Very High & 18 & 60 & 0 & 0 \\
$61-80$ & Height & 12 & 40 & 15 & 50 \\
$41-60$ & Enough & 0 & 0 & 10 & 33,33 \\
$21-40$ & Low & 0 & 0 & 5 & 16,67 \\
$0-20$ & Very Low & 0 & 0 & 0 & 0 \\
\hline Amount & & 30 & 100 & 30 & 100 \\
\hline
\end{tabular}

The frequency distribution of the response of students can be drawn in the form of a line diagram as shown in Figure 2.

Students' response analysis data for the control class showed that the average response of students on the learning field of industrial electronics expertise using the conventional 
method was 62.44. The median for the control class was 61 , the mode for the control class was 60 . While the variance for the control class was 155.84 . The lowest score was 40 and the highest value was 79 with range of 39 .

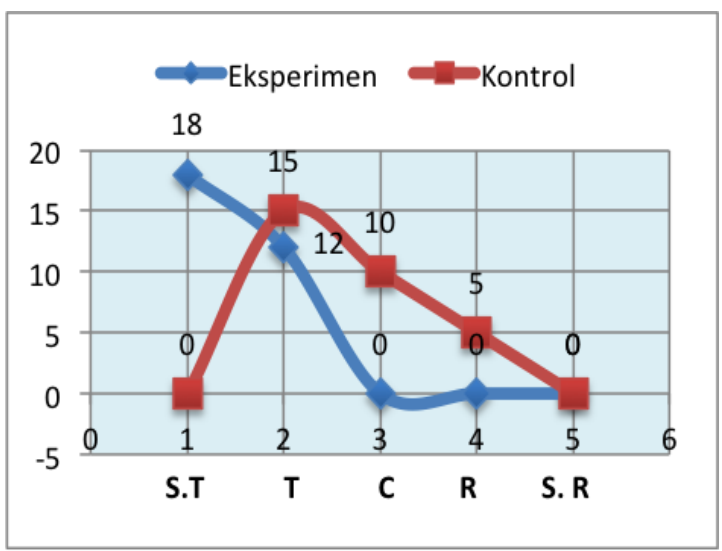

Figure 2. Frequency Chart of Student Response Response in Experiment Class and Control class

According to Table 1, the response of students to the experimental class is in very high category. This is seen in the distribution of response that are concentrated only on very high categories. Response trends of experimental class and control class are seen as different. In experiment class, the percentage in very high category was $60 \%$ and high category was $40 \%$. While in the control class, the percentage of students in high category was $50 \%$, mid category $33.33 \%$ and low category $16.67 \%$.

\section{Students Learning Outcomes in the Use of Metacognition-Based Learning Tools}

Average trends in students' learning outcomes on metacognition-based the field of industrial electronics expertise learning differed between experimental and control classes, 87.11 and 65.33. The median for the experimental class was 85 and for the control class was 60 . The mode for the experimental class was 80 and in the control class 80 . The variance for the experimental class was 48.84 and for the control class was 196.63. The lowest score for the experimental class was 80 and the highest score 100 with the range of 20. The learning outcomes of the control class students with the lowest score of 40 and the highest score of 80 with the range of 40 .

Based on these results, it could be inferred that the students' learning outcomes in the experimental percentage category included in very high category was $70 \%$ and the high category was $30 \%$. In the experimental class, there was not any student included in mid category. The percentage of control class students in high category was $46.67 \%$ and the mid category was $40 \%$, the low category was $13.33 \%$.

Tabel 2. Frequency distribution of learning outcomes of learners based on meta-cognition and Conventional

\begin{tabular}{cccccc}
\hline \multirow{2}{*}{ Value } & \multirow{2}{*}{ Category } & \multicolumn{2}{c}{ Experiment } & \multicolumn{2}{c}{ Experiment } \\
\cline { 3 - 6 } & & Freq. & $\%$ & Freq. & $\%$ \\
\hline $81-100$ & Very High & 21 & 70 & 0 & 0 \\
$61-80$ & Height & 9 & 30 & 14 & 46.67 \\
$41-60$ & Enough & 0 & 0 & 12 & 40 \\
$21-40$ & Low & 0 & 0 & 4 & 13.33 \\
$0-20$ & Very Low & 0 & 0 & 0 & 0 \\
\hline
\end{tabular}

Description:

$$
\begin{array}{ll}
\text { S.T } & =\text { Very High } \\
\mathrm{T} & =\text { Height } \\
\mathrm{C} & =\text { Enough } \\
\mathrm{R} & =\text { Low } \\
\text { S.R } & =\text { Very Low }
\end{array}
$$

Data of frequency distribution of learning result score of experimental class and control class students are provided in Figure 3.

Furthermore, the gain value is obtai-ned from the difference of posttest value and pretest value. Learning outcomes are the results obtained by the students after learning, then the learning outcomes in question is an increase experienced by students in growing HOTS skills. In order to figure out the effectiveness of the use of metacognitionbased learning tools in the experimental class and the use of direct learning in the control class, the gain calculation was used. The results from the normalized gain calculation $(\mathrm{g})$ in the experimental class and control class can be seen in Table 3 . 


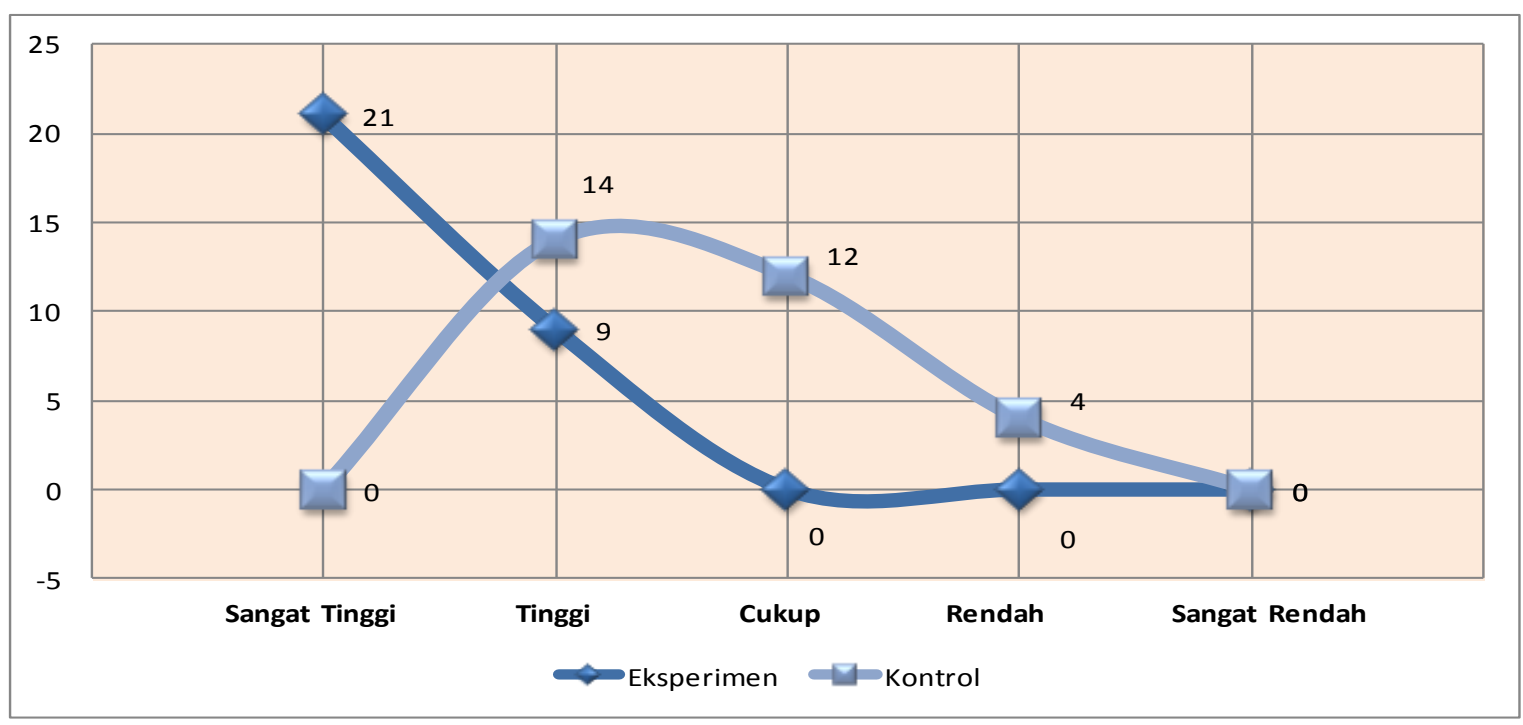

Figure 3. Trends in Learning Outcomes of Experimental Class and Control Class

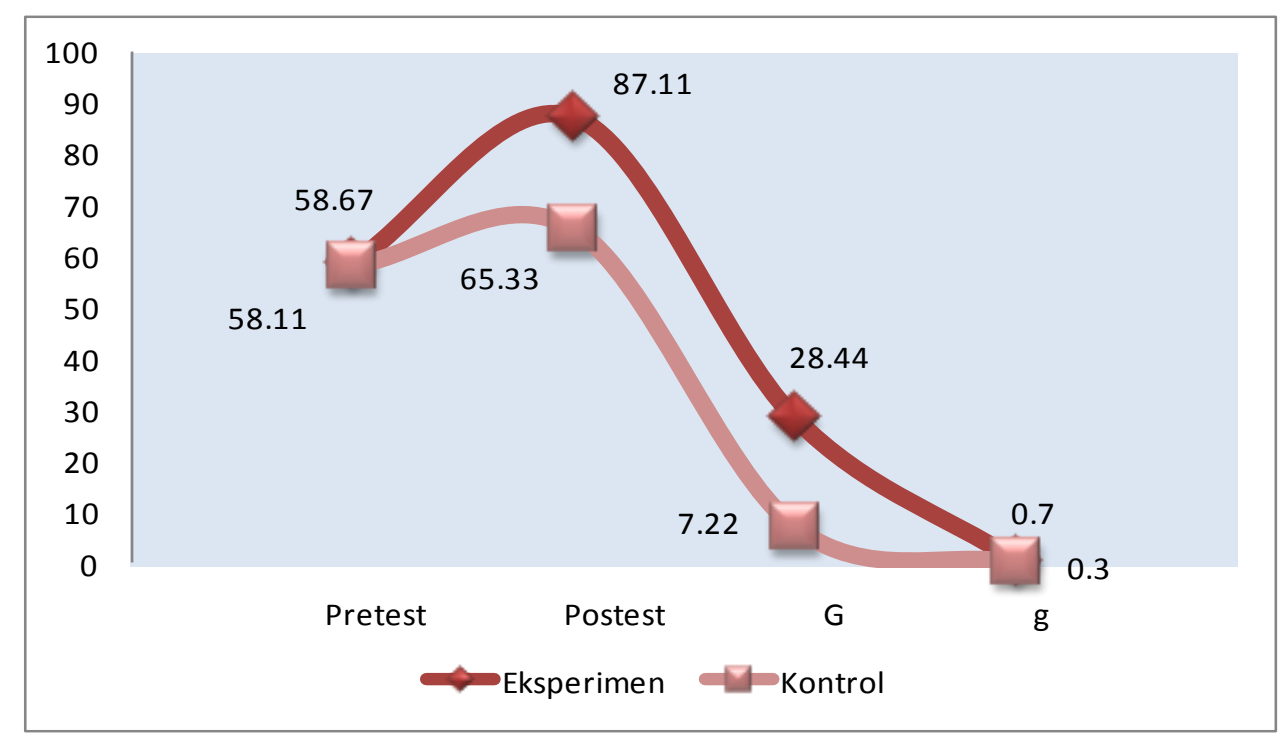

Figure 4. Results of the Experiment Class Gain and Control Class

Tabel 3. Results of Experimental and Control Class Gain Index

\begin{tabular}{cccccc}
\hline Class & Pretest & Posttest & Gain & $\mathrm{g}$ & Criteria \\
\hline $\begin{array}{r}\text { Experi- } \\
\text { mental }\end{array}$ & 58,67 & 87,11 & 28,44 & 0,7 & Height \\
Control & 58,11 & 65,33 & 7,22 & 0,3 & Low \\
\hline
\end{tabular}

Based on pretest and posttest score data in the experimental class, the gain values of normalized experimental class is 0.7 and control class was 0.3 . The value was interpreted into the criteria of value $(\mathrm{g})$, in which it was obtained the effectiveness of the use of metacognition-based learning devices in experimental class is classified High.

\section{The Effectiveness of the use of Metacognition-Based Learning Tools}

Analysis of the effectiveness of the use of metacognition-based learning tools was performed by using t test in which previously underwent normality analysis requirements and data homogeneity. Based on these tests, the data that met the normal criteria $(\mathrm{P}=$ $0.200>0.05)$ and homogeneous $(P=0.276>$ $0.05)$. Then, the $t$ test analysis resulted in $t_{\text {count }}$ 
of 5.855. By looking at the distribution table $t$, it obtained $t_{\text {table }}$ with $\mathrm{df}(\mathrm{n}-2)$ or $60-2=58$ with 2-sided test (significance $=0.025$ ) and the $t_{\text {table }}$ obtained was 2,002. Then it could be concluded that $t_{\text {count }}>t_{\text {table }}$ and $\mu 1 \neq \mu 2$ which meant $\mathrm{H} 1$ was accepted, meaning that the use of metacognition-based learning tools was effective to grow HOTS.

\section{DISCUSSION OF RESEARCH RESULTS}

From the result of data analysis, it was found that experimental class and control class was an indicator in determining the metacognition-based learning effectiveness in the field of industrial electronic. The learning outcomes development trend of experimental class was higher than control classes and it was caused by the high response of students in studying metacog-nition-based industrial electronics expertise. The high response could improve the ability of students in implementing the learning process. The experimental class was given treatment in the learning activity so that students were challenged to think creatively in analyzing the industry electronics circuits by using HOTS, while the learning activity in control class was conducted generally in the classroom by using direct learning method.

To find out the effectiveness of the use of metacognition-based learning tools in the field of industrial electronics expertise, the normalized gain calculation was used either in the experimental class or in the direct learning class. The $\mathrm{g}$ value for the experimental and control group as the result of test calculation using normalized gain was obtained by noticing the difference between the groups.

The results of this study are expected to contribute in overcoming the low achievement of the students, especially on productive learning and can be applied in overcoming the problems of education in general. Learning in vocational schools is usually constrained by lack of facilities, infrastructure of laboratory facilities.

The HOTS competence of students can be grown continuously in order to be able to face their roles in DUDI. The educator's job is to find the right method using existing facilities without compromising the essence of this learning skill. Kipnis \& Hofstein (2008, p. 1) described the results of a study conducted by Schraw which found that of the 20 students who were analyzed, metacognitive activity resulted in an appropriate plan to train metacognitive skills in conducting laboratory investigation activities. Some research results that examine the skills of thinking in learning suggest that HOTS is indispensable in carrying out work in industry in the $21^{\text {st }}$ century. Where manual work on the industry is replaced with computer programming applications that require HOTS capabilities.

The metacognitive learning approach is the right solution in overcoming the lack of understanding of learners to develop HOTS capabilities. The results of this study prove that metacognitive-based learning is a practical, easy and interesting approach as shown from the students' responses and high learning outcomes in using metacognition learning tools in which its learning syntax leads to the ability of HOTS. The study conducted by Chang, Ku, \& Yu (2011, p. 53) on the metacognition of students in Taiwan vocational schools was still in the early stages of development. This study aimed at exploring the differences of the four stages of metacognition, namely: understanding problems, planning, implementation and verification of metacognitive ability. The results showed that the participants could easily perform metacognition procedures, through understanding the problem (classif-ying problems easily), planning (following complex operations planning), implementa-tion (controlling accurate questions), and verification (comparing and verifying with different scenarios) could build an effective self-efficacy.

\section{CONCLUSION}

Based on the analysis of the effectiveness of metacognition-based learning tools in the field of industrial electronics expertise, the following research results were obtained. (1) The students' response to the use of metacognition-based learning tools was very high in the learning process. High students' response was indicated by the magnitude of the positive response to the use of the tools. (2) Trends in learning outcomes of students. The average trend of learning outcomes of experimental class learners was higher. (3) The use of metacognition-based learning tools in the field of Industrial Electronics Expertise was effective for growing HOTS capabilities. 


\section{REFERENCES}

Amalathas, E. (2010). Learning to learn in further education. A literature review of effective practice in England and abroad. Retrieved from www.cfbt.com

Chang, S.-H., Ku, A.-C., \& Yu, L.-C. (2011). Analysing practical skills of vocational school students in metacognition - a case study of an electronic practical course in Taiwan. In 2nd WIETE Annual Conference on Engineering and Technology Education (pp. 53-57). Pattaya: World Institute for Engineering and Technology Education (WIETE). Retrieved from http://www.wiete.com.au/conferences/2 wiete/Pages/12-16-Ku.pdf

Dharma, S., Sugiyono, Mulyatinigsih, E., Sutopo, Irwanto, Palusu, J. E., ... Siswanto, R. (2013). Tantangan Guru SMK Abad 21. Jakarta: Direktorat Pembinaan Pendidikan dan Tenaga Kependidikan Menengah, Direktorat Jenderal Pendidikan Menengah, Kementerian Pendidikan Menengah.

Direktur Jenderal Pendidikan Menengah Kementerian Pendidikan dan Kebudayaan. Surat Keputusan tentang Spektrum Pendidikan SMK, Pub. L. No. 7013/D/KP/2013 (2013). Indonesia.

Faraday, S., Overton, C., \& Cooper, S. (2011). Effective teaching and learning in vocational education. London: LSN. Retrieved from http://www.coopergibson.co.uk/110052 RP_effective VET_final report.pdf

Flavell, J. H. (1979). Metacognition and cognitive monitoring: A new area of cognitive-developmental inquiry. American Psychologist, 34(10), 906911. https://doi.org/10.1037/0003066X.34.10.906

Hopkins, D. (2007). Every school a great school : realizing the potential of system leadership. McGraw-Hill/Open University Press.

Jossberger, H., Brand-Gruwel, S., van de Wiel, M. W. J., \& Boshuizen, H. P. A. (2015). Teachers' perceptions of teaching in workplace simulations in vocational education. Vocations and Learning, $\quad 8(3), \quad 287-318$. https://doi.org/10.1007/s12186-0159137-0

Kerka, S. (1992). Higher order thinking skills in vocational education. Retrieved April 29, 2008, from https://www.ericdigests.org/19921/order.htm

Kipnis, M., \& Hofstein, A. (2008). The inquiry laboratory as a source for development of metacognitive skills. International Journal of Science and Mathematics Education, 6(3), 601-627. https://doi.org/10.1007/s10763-0079066-y

Kompas. (2016). Kompas Edisi Senin 2 Mei 2016. Retrieved from https://kompashariini.blogspot.co.id/201 6/05/kompas-edisi-senin-2-mei-

2016.html

Ku, K. Y. L., \& Ho, I. T. (2010). Metacognitive strategies that enhance critical thinking. Metacognition and Learning, 5(3), 251-267. https://doi.org/10.1007/s11409-0109060-6

Kung, R., Danielsson, A., \& Linder, C. (2005). Metacognition in the student laboratory: Is increased metacognition necessarily better? Retrieved March 10, 2010, from http://journals.ohiolink.edu.proxy.lib.ohi o-state.edu/ejc/pdf

Lai, E. R. (2011). Metacognition: A literature review. Retrieved from http://images.pearsonassessments.com/i mages/tmrs/metacognition_literature_rev iew_final.pdf

Lee, M., \& Baylor, A. L. (2006). Designing metacognitive maps for web-based learning. Journal of Educational Technology \& Society, 9(1), 344-348. Retrieved from http://www.ifets.info/journals/9_1/28.pd $\mathrm{f}$

Livingston, J. A. (1997). Metacognition: An overview. Retrieved December 23, 2008, from http://gse.buffalo.edu/fas/shuell/cep564/ 
metacog.htm

Lucas, B., Spencer, E., \& Claxton, G. (2012). How to teach vocational education: A theory of vocational pedagogy. London: Centre for Real-World Learning at the University of Winchester. Retrieved from

http://www.winchester.ac.uk/aboutus/lif elonglearning/CentreforRealWorldLearn ing/Documents/How-to-teachvocational-education Bill Lucas Ellen Spencer and Guy Claxton.pdf

Munby, H., Hutchinson, N. L., \& Chin, P. (2009). Workplace learning: metacognitive strategies for learning in the knowledge economy. In R. Maclean \& D. Wilson (Eds.), International Handbook of Education for the Changing World of Work (pp. 17631775). Dordrecht: Springer Netherlands. https://doi.org/10.1007/978-1-4020-

5281-1_119
Sudira, P. (2016). TVET abad 21 filosofi, teori, konsep, dan strategi pembelajaran vokasional. Yogyakarta: UNY Press.

Supardi. (2013). Sekolah efektif. Jakarta: PT. Raja Grafindo Persada.

Susanto, A. (2013). Teori belajar \& pembelajaran di sekolah dasar. Jakarta: Kencana Prenada Media Group.

Trisdiono, H. (2013). Strategi pembelajaran abad 21. Retrieved from http://lpmpjogja.org/strategipembelajaran-abad-21/

Wijaya, E. Y., Sudjimat, D. A., \& Nyoto, A. (2016). Transformasi pendidikan abad 21 sebagai Tuntutan pengembangan sumber daya manusia di era global. In Prosiding Seminar Nasional Pendidikan Matematika 2016. Universitas Kanjuruhan Malang. 